\title{
АНАЛИЗ ЭФФЕКТИВНОСТИ ПРИМЕНЕНИЯ МЕТОДОВ СТРАТЕГИЧЕСКОГО АНАЛИЗА В ГОСУДАРСТВЕННОМ УПРАВЛЕНИИ, НА ПРИМЕРЕ РЕСПУБЛИКИ ДАГЕСТАН
}

\author{
(c) 2019 Джамалудинова Мадина Юнускадиевна
}

кандидат экономических наук, доцент кафедры «Государственное и муниципальное управление» Дагестанский государственный университет, Россия, Махачкала

E-mail: madina0880@mail.ru

\section{(c) 2019 Абдулаев Шамиль Абдулаевич}

студент магистратуры 2 года обучения, кафедра «Государственное и муниципальное управление» Дагестанский государственный университет, Россия, Махачкала

E-mail: A.shamil89@mail.ru

Социально-экономическое развитие любого региона предполагает расширенное воспроизводство и постепенные качественные и структурные положительные изменения экономики, производительных сил, факторов роста и развития образования, науки, культуры, уровня и качества жизни населения. Опережающее развитие экономики Республики Дагестан сегодня основывается на реализации накопленного потенциала, инвестиционных проектах и государственных программах, приоритетных проектах развития Республики Дагестан, поддержании конкурентоспособности местных производителей, стимулировании экономического роста и модернизации экономики.

Ключевые слова: стратегическое планирование, инвестиции, социально-экономическое развитие, долгосрочная перспектива, консолидированный бюджет, эффективность.

В настоящее время Республика Дагестан сталкивается с долгосрочными системными проблемами, отражающими как российские, так и мировые тенденции, а также внутренние барьеры развития:

- усиление глобальной конкуренции против формирования новых точек роста мировой экономики «БРИК + 11» с акцентом на особую роль Азии и интеграционные возможности Республики Дагестан. Усиление роли федерального центра и конкуренции между субъектами Российской Федерации;

- создание Северо-Кавказского федерального округа. Возрастающая роль человеческого капитала, инноваций и модернизации как основных факторов экономического развития при уменьшении влияния многих традиционных факторов роста;

- исчерпание потенциала ресурсной модели экономического развития, основанной на доиндустриальных отраслях и акценте на низкой стоимости факторов производства - рабочей силы, топлива, электроэнергии.

Основными приоритетами и целями развития республики в краткосрочной и среднесрочной перспективе являются руководящие указания по разработке прогноза социально- экономического развития Республики Дагестан на 2018 год и планового периода на 2019 и 2020 годы.

В 2018 году рост предполагаемого ВРП составил 101,5\%; промышленное производство - 110,4\%; сельскохозяйственная продукция - 102,7\%; инвестиции в основной капитал - 100,0\%; выполненные работы по виду деятельности «Строительство» - 100,2\%; оборот розничной торговли $-102,3 \%$; среднемесячная заработная плата - 104,7\%; реальные располагаемые доходы населения - 100,2\% [4, с. 33].

В 2018-2020 гг. среднегодовая динамика инвестиций в основной капитал составит $0,3 \%$ по консервативному варианту, 2,5\% по базовому варианту и 5,2\% по целевому варианту.

Прогнозные показатели доходов консолидированного бюджета Республики Дагестан на 2018 год и плановый период 2019 и 2020 годов рассчитаны на основе действующего законодательства и предполагают увеличение налоговой базы. Согласно прогнозу на 2020 год, объем налоговых и неналоговых поступлений по показателю вариантности вырастет на 6,8\%, 7,5\% и 14,6\% по сравнению с 2017 годом.

В среднесрочной перспективе планируется улучшить показатели социального развития и 
повысить эффективность социальной политики. Предполагается, что рост реальных денежных доходов населения будет обеспечиваться за счет снижения инфляции, увеличения среднего размера трудовой пенсии и ее индексации, а также роста заработной платы в секторах экономики республики.

Основной стратегической целью Республики Дагестан является повышение качества жизни населения на основе повышения конкурентоспособности региона, устойчивого экономического развития и безопасности.

Реализация основной стратегической цели позволит достичь уровня экономического и социального развития, соответствующего статусу Республики Дагестан как важнейшего субъекта Российской Федерации XXI века. Согласно Стратегии социально-экономического развития до 2020-2025 гг. республика должна войти в двадцатку ведущих субъектов по объему валового регионального продукта и индексу развития человеческого потенциала.

Увязать стратегию РД до 2035 г., соответственно стратегические цели и приоритеты развития республики со стратегией СКФО до 2030 г. будет сложно, если вообще возможно. Это, в свою очередь, может вызвать сложности для участия республики в федеральных программах, в реализации национальных проектов (программ), разрабатываемых в соответствии с Указом Президента РФ от 7 мая 2018 года № 204 (майский указ Президента РФ 2018 г.) и др. [6, с. 66].

Для Дагестана активное участие в этих и других программах и проектах Российской Федерации и СКФО чрезвычайно важно с целью получения и использования ресурсов из этих источников для социально-экономического развития и решения стратегических задач. Именно поэтому целесообразно обстоятельно обсудить и концептуально решить вопрос о временном горизонте новой стратегии социальноэкономического развития РД.

При этом следует также учитывать, что регионы России, например, Санкт-Петербург, Республика Татарстан, Красноярский край, Свердловская, Самарская, Иркутская, Томская, Архангельская области и др., имеют стратегии до 2030 года. Очевидно, такой временной горизонт является оптимальным для стратегического планирования, учитывая интенсивные процессы глобализации, смены технологических укладов, геополитической и экономической нестабильности в мире. Вместе с тем прогнозирование социально-экономического развития РД целесообразно осуществлять не только до 2030 г., но и на более долгосрочный период, например, до 2040 г., а по отдельным индикаторам, возможно, и до 2050 г [2, с. 40].

Вопреки исходным положениям Федерального закона в Республике Дагестан не осуществляется стратегическое планирование на муниципальном уровне и не разрабатываются предусмотренные Федеральным законом стратегические документы долгосрочного социально-экономического развития муниципальных образований. Отсутствие взаимоувязанной цельной системы стратегического планирования социально-экономического развития республики и муниципальных образований является одной из основных факторов разобщенности целей и задач структур управления республиканского и муниципального уровня, отсюда - неэффективности всей системы организации и управления экономическим и социальным развитием республики [1, с. 117].

Республика располагает всеми природными, трудовыми и производственными ресурсами для прорывного развития и преодоления отставания. Нужна кардинальная модернизация организации хозяйственного комплекса и системы государственного и муниципального управления [6, с. 7].

При определении главной стратегической цели Республики Дагестан необходимо учитывать, что в условиях глобализации и открытого мирового рынка российский, в том числе и дагестанский республиканский, рынки становятся сегментами глобального мирового рынка. Экономике Дагестана, как и России в целом, необходимо обеспечить конкурентоспособность на этом глобальном рынке. Вместе с тем республике предстоит принять активное участие в реализации майского указа Президента РФ 2018 г. «О национальных целях и стратегических задачах развития Российской Федерации на период до 2024 года», где в числе других поставлены весьма амбиционные задачи войти в число пяти крупнейших экономик мира и обеспечить ускорение технологического развития Российской Федерации. Для выполнения такой сложной задачи России, ее регионам, в том числе и Дагестану, необходимо преодолеть отставание и совершить прорыв в экономическом, социальном и технологическом развитии [5, с. 48]. 
Особую тревогу должно вызывать техническое и технологическое отставание России, что в условиях глобализации и открытого мирового рынка неизбежно влечет за собой неконкурентоспособность и постепенное вымирание отдельных отраслей и сфер экономики. По оценке зарубежных экспертов, например, в экономике США доля четвертого технологического уклада составляет $20 \%$, пятого - $60 \%$ и шестого - $5 \%$, а в России все еще $30 \%$ - экономика третьего технологического уклада, $50 \%$ четвертого и всего $10 \%$ пятого, а до шестого технологического уклада российская экономика вообще еще не добралась [2, с. 40]. Если судить по этим данным, то экономике России нужно преодолеть техническое отставание от США примерно в один технологический уклад.

При таком отставании России от развитых стран мира Дагестан по состоянию на 2016 г. в разы отстает от среднероссийского уровня практически по всем макроэкономическим показателям. Дагестан отстает в расчете на душу населения по показателям: ВРП - в 2,4 раза, объему промышленной продукции - в 20 раз, стоимости основных фондов - в 2,5 раза, объему инвестиций в основной капитал - в 1,4 раза, производительности труда - в 1,7 раза. При этом удельный вес инновационных товаров, работ и услуг в общем объеме отгруженных в России составлял 8,5\%, в Республике Дагестан - 0,4\% (меньше в 21,3 раза), а удельный вес организаций, осуществляющих технологические инновации, $-8,4 \%$ и $2,5 \%$ (меньше в 3,4 раза) соответственно [3, с. 73].

Такое состояние экономики неизбежно привело к отсутствию достаточной доходной базы и дефициту бюджетной системы, отставанию развития социальной сферы и уровня жизни населения республики. Дотационность консолидированного бюджета составляет 76\%. Среднемесячная номинальная зарплата в 1,8 раза ниже среднероссийской, безработица выше почти вдвое, совокупные бюджетные расходы из консолидированного бюджета на душу населения меньше в 2 раза, чем в среднем в российских регионах [1, с. 122].

Еще более опасным следствием отставания является то, что в поисках работы и нормальных современных условий жизни ежегодно из республики уезжают десятки тысяч самых активных и дееспособных дагестанцев. Основные мотивы миграции дагестанцев связаны с неудовлетво- ренностью качеством жизни в регионе, поиском работы, причинами личного и семейного характера. Причем от 77\% до 80\% выезжающих из Дагестана составляют граждане в трудоспособном возрасте.

За последние 10 лет даже по официальным данным отрицательный баланс миграции из Дагестана составил 146 тыс. человек, из них около 117 тыс. в трудоспособном возрасте. Если бы эти дагестанцы оставались и трудились в республике по средней производительности занятых (609 тыс. р.), то могли бы в 2016 г. создать свыше 71 млрд. руб. ВРП и внести в консолидированный бюджет около 4 млрд. руб. налоговых и неналоговых платежей [2, с. 30].

Таков далеко неполный годовой экономический ущерб миграции населения из Дагестана в другие регионы России и зарубежные страны. Конечно, гораздо большую опасность сложившийся устойчивый тренд миграции представляет как процесс рассасывания дагестанцев, потери их идентичности, а в определенной долговременной перспективе и как угроза распада Дагестана. Поэтому отставание - главная угроза и враг не только всей России, но и Дагестана, всего дагестанского общества.

Преодоление этих угроз, прорывное развитие, преодоление отставания и выравнивание уровня социально-экономического развития необходимо рассматривать как важнейшую стратегическую задачу органов власти и всего дагестанского общества. Именно поэтому Глава Дагестана В. Васильев в одном из своих выступлений совершенно обоснованно подчеркнул, что Дагестану надо выйти на средние показатели России по социально-экономическому развитию.

Из всего этого вытекает, что главной долгосрочной стратегической целью республики должно быть преодоление отставания и выход на средние макроэкономические показатели России по уровню экономического и социального развития.

Основная задача разрабатываемой стратегии состоит именно в том, чтобы дать ясный и четкий ответ на вопрос: как, в какие сроки и какими средствами решить эту главную стратегическую задачу, какие ресурсы для этого нужны и где их взять.

Во-первых, надо всем дагестанцам, особенно молодому поколению, освоить одну истину - выводить республику из социально- 
экономического кризиса и обеспечить достойный уровень жизни можно только своим трудом, собственными силами и средствами. Конечно, с помощью Федерального центра, которую можно получить опять-таки только благодаря умелой организации и эффективной работе, активному участию в реализации федеральных государственных программ, планов и иных проектов.

Во-вторых, надо понять, что хроническое отставание последние три десятилетия - это отнюдь не результат недееспособности дагестанцев и не связано с недостатком ресурсов. Республика располагает всеми природными, трудовыми и производственными ресурсами для прорывного развития и преодоления отставания. Нужна кардинальная модернизация ор- ганизации хозяйственного комплекса и системы государственного и муниципального управления.

Таким образом, стоит отметить, что снижение уровня экономического развития приводит к снижению доходов и потребления всего населения страны, и, если одновременно резко возрастает социальная дифференциация, основная часть населения несет еще большие экономические потери. Поэтому остается только одно - предотвращение подобных ситуаций и принятие мер по устранению существующих процессов или явлений на благо своей республики и страны в целом. В связи с этим, в 2019 году будет продолжена работа по реализации мероприятий приоритетных программ комплексного развития региона.

\section{Библиографический список}

1. Авдашева С. Государственная поддержка в регионах: состояние и проблемы реорганизации // Вопросы экономики. 2018. № 5. С. 113-124.

2. Агаев Р.П., Чеботарев П.Ю. Сходимость и устойчивость в задачах согласования характеристик (обзор базовых результатов). /В сборнике статей (под редакцией Д.А. Новикова, О.П. Кузнецова, М.В. Губко). М.: Эгвес, 2018. C. 8-43.

3. Асадулаева Ш.Р. Социально-экономическая политика Республики Дагестан // Экономика и современный менеджмент: теория, методология, практика: сборник статей V Международной научно-практической конференции. 2019. С. 73-75.

4. Рамазанова А.Г., Максубова Д.М. Совершенствование механизма социально-экономического развития региона на примере Республики Дагестан // В сборнике: WORLD SCIENCE: PROBLEMS AND INNOVATIONS сборник статей XXVIII Международной научно-практической конференции: в 2 ч.. 2019. C. 32-34.

5. Chaharbaghi K., Lynch $R$. Sustainable competitive advantage: towards a dynamic resource-based strategy // Management Decisions. 1999. Vol. 37. No. 1. P. 45-50.

6. David Fred R., David Forest R. Strategic Management. A Competitive Advantage Approach, Concepts and Cases, Global Edition. 16th ed.- Pearson, 2017.- P. 101. 